\title{
Effect of Irrigation Levels and Mulch on Growth and Yield of Cucumber (Cucumis sativus L.) under Poly House
}

\author{
Om Prakash Rolaniya ${ }^{1 *}$, I. M. Verma ${ }^{1}$, S. R. Bhunia ${ }^{2}$ and Suresh Kumar Choudhary ${ }^{1}$ \\ ${ }^{1}$ Department of Horticulture, College of Agriculture, SKRAU, Bikaner-334006, \\ Rajasthan, India \\ ${ }^{2}$ Department of Agronomy, College of Agriculture, SKRAU, Bikaner-334006, Rajasthan, India \\ *Corresponding author
}

\section{A B S T R A C T}

Research results indicated significant variation in all the vegetative growth attributes and yield parameters in different drip irrigation and mulches. The maximum number of

Keywords

Cucumber

(Cucumis sativus

L.), Poly-house

\section{Article Info}

Accepted:

28 February 2018

Available Online:

10 March 2018 branches per vine, length of vine, number of leaves per vine and leaf area were recorded with 1.0 ETc as compared to other drip irrigation treatments at 60, 90 DAT and harvest. However, in respect to earliness i.e. days to first flowering, fruiting and harvesting were also observed with the treatment 1.0 ETc. The maximum fruit length $(13.04 \mathrm{~cm})$, fruit girth $(3.67 \mathrm{~cm})$, average fruit weight $(110.52 \mathrm{~g})$, number of fruits per vine (12.99), fruit yield per vine $(1.39 \mathrm{~kg})$ and Further, $0.8 \mathrm{ETc}$ gave at par values for all these parameters with 1.0 ETc. Among various mulching; number of branches per vine, length of vine, number of leaves per vine $(27.32)$, leaf area $\left(405.75 \mathrm{~cm}^{2}\right)$ and yield attributes namely, fruit length $(13.16 \mathrm{~cm})$, fruit girth $(3.55 \mathrm{~cm})$, number of fruits per vine $(11.91)$, average fruit weight $(110.83 \mathrm{~g})$, fruit yield per vine $(1.37 \mathrm{~kg})$ and fruit yield per hectare $\left(561.31 \mathrm{q} \mathrm{ha}^{-1}\right)$. The treatment combination of $1.0 \mathrm{ETc}+$ black polythene mulch gave higher values for number of fruits per vine (13.48), fruit yield per vine $(1.51 \mathrm{~kg})$ and fruit yield $\left(622.55 \mathrm{q} \mathrm{ha}^{-1}\right)$.

\section{Introduction}

Cucumber (Cucumis sativus L.) belonging to family cucurbitaceae is one of the important vegetable crops from nutritional as well as economic point of view. The fruit cucumber is said to have cooling effect, prevent constipation, checks jaundice and indigestion (Nandkarni, 1927). The major cucumber growing pockets in Rajasthan are Bharatpur, Alwar, Bhilwara, Jaipur, Tonk, Dholpur and Sawai Madhopur districts. Hence, judicious use of the available water resources through more efficient methods of water application like drip irrigation under conditions of protected cultivation becomes necessary to enhance yield and water use efficiency (Dunage et al., 2009).

Polyhouse technology is a breakthrough in the agricultural production technology that integrates market driven quality parameters with the production system with high monetary return. In the present scenario of ever increasing demand of vegetables and shrinking land holding, protected cultivation 
technology is the best alternative for using land and other resources more efficiently.

\section{Materials and Methods}

The experiment was laid out at $\mathrm{Hi}$-tech Nursery, SKRAU, in agro-climatic zone, Bikaner comes under Ic (Hyper Arid Partially Irrigated North-Western Plain) zone of Rajasthan. The experiment was laid out in Split plot Design with four replications. There were three level of irrigation viz., 0.6 ETc $\left(\mathrm{I}_{1}\right)$, 0.8 ETc $\left(\mathrm{I}_{2}\right)$ and 1.0 ETc $\left(\mathrm{I}_{3}\right)$ and three treatment of mulching materials viz., without mulch $\left(\mathrm{M}_{0}\right)$, Black polythene mulch $\left(\mathrm{M}_{1}\right)$ and Straw mulch $\left(\mathrm{M}_{2}\right)$. To apply nine treatment combination such as $\mathrm{I}_{1} \mathrm{M}_{0}, \mathrm{I}_{1} \mathrm{M}_{1}, \mathrm{I}_{1} \mathrm{M}_{2}, \mathrm{I}_{2} \mathrm{M}_{0}$, $\mathrm{I}_{2} \mathrm{M}_{1}, \mathrm{I}_{2} \mathrm{M}_{2}, \mathrm{I}_{3} \mathrm{M}_{0}, \mathrm{I}_{3} \mathrm{M}_{1}$ and $\mathrm{I}_{3} \mathrm{M}_{2}$. The region is characterized by deep, coarse sandy and desert soil with low water holding capacity and poor fertility and low productivity. Daily irrigation schedule through drip was applied on basis of ETc levels i.e. $\mathrm{PE}_{\mathrm{x}} \mathrm{Kp}{ }_{\mathrm{x}} \mathrm{Kc}$ considering $\mathrm{Kc}$ values to be $0.80,1.00$ and 0.80 for initial (25 days), crop development (95 days) and final (30 days) stages, respectively. The field area selected was $544.32 \mathrm{~m}^{2}$. The field was divided into 36 plots $\left(1\right.$ plot $\left.=15.12 \mathrm{~m}^{2}\right)$ in which plots were laid with drip irrigation. Each bed had one lateral line having drippers with an average emitter operating. Spacing of $40 \mathrm{~cm}$ provided between the two emitters.

\section{Results and Discussion}

\section{Growth attributes}

\section{Number of branches per vine}

Data presented in table 1 revealed that different drip irrigation levels and mulches influenced the number of branches per vine at 60, 90 DAT and harvest. Irrigation level of 1.0 ETc gave maximum number of branches of $1.75,1.81$ and 1.96 per vine at 60, 90 DAT and harvest, respectively and in case of black polythene mulch recorded maximum number of branches per vine i.e., $(1.71,1.77$ and 1.92 at 60, $90 \mathrm{DAT}$ and harvest, respectively).

\section{Length of vine (m)}

Data (Table 1) showed that different drip irrigation levels had significant influence on length of vine at 60, 90 DAT and harvest. Irrigation level at $1.0 \mathrm{ETc}$ gave the maximum length of vine viz., 3.49, 3.63 and $3.77 \mathrm{~m}$ and in case of mulches black polythene mulches the maximum was recorded under black polythene mulch $(3.72,3.84$ and 3.97 at 60,90 DAT and harvest, respectively).

\section{Number of leaves per vine}

Results presented in table 1 revealed that different drip irrigation levels and mulches significantly influenced number of leaves per vine at 60 and 90 DAT. Irrigation level of 1.0 ETc recorded maximum number of leaves per vine viz., 23.91 and 28.28 at 60 and 90 DAT, respectively. In black polythene mulch number of leaves per vine was recorded maximum at 60 (22.55) and 90 (27.32) DAT.

\section{Leaf area per plant}

Data presented in table 1 indicated that various drip irrigation levels and application of different mulches significantly influenced the leaf area per plant at 60 and 90 DAT. Irrigation level of 1.0 ETc and black polythene mulch recorded the maximum leaf area per plant 388.38, $402.84 \mathrm{~cm}^{2}$ and $391.19 \mathrm{~cm}^{2}$, $405.75 \mathrm{~cm}^{2}$ at 60 and 90 DAT, respectively.

\section{Flowering attributes}

\section{Days to first flowering}

Critical examination of data presented in table 2 indicated that different levels of drip irrigation and various type of mulches 
significantly influenced days to first flowering'. Data recorded that in Irrigation level at 1.0 ETc and black polythene mulch promoted early flowering.

\section{Days to first fruiting}

The data on 'days to first fruiting' as influenced by different irrigation levels and effect of mulches are presented in table 2 .

The perusal of data revealed that days to first fruiting was minimum (42.79 days) under 1.0 ETc irrigation level and in case of black polythene mulch (41.71 days) was recorded.

\section{Days to first fruit harvest}

Experimental data (Table 2) showed that different levels of drip irrigation and various type of mulches had significant effect on days to first fruit harvest.

Irrigation level of 1.0 ETc was the earliest (45.24 days) to first fruit harvesting but, remained statistically at par with 0.8 ETc.

Effect of mulching Black polythene mulch (44.11) took less number of days for first fruit harvest compared to straw mulch (44.99 days).

\section{Yield and yield attributes}

\section{Fruit length (cm)}

Data indicated that significantly maximum fruit length $(13.04 \mathrm{~cm})$ was recorded under 1.0 ETc as compared to 0.6 ETc, though remained statistically at par with 0.8 ETc (Table 4.6).

Effect of mulching data presented in table 2 revealed that maximum fruit length was recorded with black polythene mulch (13.16 $\mathrm{cm})$ followed by straw mulch $(12.10 \mathrm{~cm})$ and minimum in without mulch $(10.18 \mathrm{~cm})$ treatment.

\section{Fruit girth (cm)}

Effect of irrigation levels indicated that significantly maximum fruit girth $(3.67 \mathrm{~cm})$ was recorded under $1.0 \mathrm{ETc}$ as compared to 0.6 ETc of drip irrigation level and in different type of mulches maximum fruit girth (3.55 $\mathrm{cm})$ was recorded with black polythene mulch compared to straw mulch $(3.44 \mathrm{~cm})$ and minimum with no mulch $(3.27 \mathrm{~cm})$ treatment.

\section{Fruit weight (g)}

A perusal of data indicated that irrigation level at $1.0 \mathrm{ETc}(110.52 \mathrm{~g})$ through drip irrigation and under black polythene mulch (110.83 g) recorded maximum significant effect on average fruit weight.

\section{Number of fruits per vine}

Data (Table 2) indicated that drip irrigation at 1.0 ETc recorded significantly higher number of fruits (12.99) per vine as compared to 0.6 ETc level of drip irrigation,

However with black polythene mulch the maximum number of fruits per vine $(11.91 \mathrm{~g})$ were recorded followed by straw mulch (11.54 g) and minimum under no mulch (10.97 g) treatment was at par with 0.8 ETc.

\section{Fruit Yield per vine}

Data regarding fruit yield per vine presented in table 2 indicated that increasing levels of drip irrigation significantly increased fruit yield per vine.

Significantly higher fruit yield $(1.39 \mathrm{~kg}$ per vine) was recorded at $1.0 \mathrm{ETc}$ as compared to 0.6 ETc irrigation level but, remained at par with 0.8 ETc of drip irrigation level. Effect of mulching that application of different types of mulches significantly influenced the fruit yield per vine. 
Table.1 Effect of irrigation levels and mulch on growth attributes of cucumber cv. Noori $\mathrm{F}_{1}$ hybrid

\begin{tabular}{|c|c|c|c|c|c|c|c|c|c|c|}
\hline \multirow[t]{2}{*}{ Treatments } & \multicolumn{3}{|c|}{ Number of branches per vine } & \multicolumn{3}{|c|}{ Length of vine (m) } & \multicolumn{2}{|c|}{ Number of leaves per vine } & \multicolumn{2}{|c|}{ Leaf area $\left(\mathrm{cm}^{2}\right)$ per plant } \\
\hline & 60 DAT & 60 DAT & 60 DAT & 60 DAT & 90 DAT & At harvest & 60 DAT & 90 DAT & 60 DAT & 90 DAT \\
\hline \multicolumn{11}{|l|}{ Irrigation levels } \\
\hline $0.6 \mathrm{ETc}$ & 1.39 & 1.39 & 1.39 & 3.13 & 3.21 & 3.31 & 17.18 & 21.93 & 331.66 & 344.09 \\
\hline $0.8 \mathrm{ETc}$ & 1.73 & 1.73 & 1.73 & 3.38 & 3.49 & 3.61 & 23.72 & 28.03 & 384.50 & 398.81 \\
\hline 1.0 ETc & 1.75 & 1.75 & 1.75 & 3.49 & 3.63 & 3.77 & 23.91 & 28.28 & 388.38 & 402.84 \\
\hline SEm \pm & 0.03 & 0.03 & 0.03 & 0.07 & 0.07 & 0.05 & 0.51 & 0.69 & 6.07 & 6.30 \\
\hline CD at $5 \%$ & 0.10 & 0.10 & 0.10 & 0.23 & 0.25 & 0.17 & 1.77 & 2.37 & 21.01 & 21.82 \\
\hline \multicolumn{11}{|l|}{ Mulch } \\
\hline Without mulch & 1.52 & 1.52 & 1.52 & 2.88 & 2.97 & 3.07 & 20.58 & 24.73 & 344.54 & 357.30 \\
\hline $\begin{array}{l}\text { Black polythene } \\
\text { mulch }\end{array}$ & 1.71 & 1.71 & 1.71 & 3.72 & 3.84 & 3.97 & 22.55 & 27.32 & 391.19 & 405.75 \\
\hline Straw mulch & 1.64 & 1.64 & 1.64 & 3.40 & 3.52 & 3.65 & 21.68 & 26.19 & 368.98 & 382.69 \\
\hline SEm \pm & 0.01 & 0.01 & 0.01 & 0.03 & 0.07 & 0.06 & 0.24 & 0.31 & 4.17 & 4.34 \\
\hline CD at $5 \%$ & 0.04 & 0.04 & 0.04 & 0.08 & 0.21 & 0.18 & 0.70 & 0.91 & 12.40 & 12.88 \\
\hline
\end{tabular}

Table.2 Effect of irrigation levels and mulch on flowering and yield attributes of cucumber cv. Noori $\mathrm{F}_{1}$ hybrid

\begin{tabular}{|c|c|c|c|c|c|c|c|c|c|}
\hline Treatments & $\begin{array}{l}\text { Days to } \\
\text { first } \\
\text { flowering }\end{array}$ & $\begin{array}{l}\text { Days to } \\
\text { first } \\
\text { fruiting }\end{array}$ & $\begin{array}{l}\text { Days to } \\
\text { first } \\
\text { harvest }\end{array}$ & $\begin{array}{l}\text { Fruit } \\
\text { length } \\
\text { (cm) }\end{array}$ & $\begin{array}{l}\text { Fruit girth } \\
\text { (cm) }\end{array}$ & $\begin{array}{l}\text { Fruit } \\
\text { weight } \\
\text { (g) }\end{array}$ & $\begin{array}{l}\text { Number of } \\
\text { fruits per } \\
\text { vine }\end{array}$ & $\begin{array}{l}\text { Fruit yield per } \\
\text { vine (kg) }\end{array}$ & $\begin{array}{l}\text { Fruit yield } \\
\qquad\left(\mathbf{q} \mathbf{h a}^{-1}\right)\end{array}$ \\
\hline \multicolumn{10}{|l|}{ Irrigation levels } \\
\hline 0.6 ETc & 38.21 & 45.22 & 47.82 & 9.91 & 2.94 & 81.02 & 8.52 & 1.02 & 405.72 \\
\hline $0.8 \mathrm{ETc}$ & 36.30 & 42.96 & 45.43 & 12.48 & 3.65 & 106.84 & 12.91 & 1.34 & 563.12 \\
\hline 1.0 ETc & 36.15 & 42.79 & 45.24 & 13.04 & 3.67 & 110.52 & 12.99 & 1.39 & 567.03 \\
\hline SEm & 0.12 & 0.18 & 0.24 & 0.23 & 0.01 & 1.26 & 0.04 & 0.02 & 1.89 \\
\hline CD at $5 \%$ & 0.42 & 0.63 & 0.84 & 0.79 & 0.04 & 4.36 & 0.15 & 0.05 & 6.55 \\
\hline \multicolumn{10}{|l|}{ Mulch } \\
\hline Without mulch & 39.47 & 46.72 & 49.40 & 10.18 & 3.27 & 85.58 & 10.97 & 1.10 & 458.88 \\
\hline Black polythene mulch & 35.24 & 41.71 & 44.11 & 13.16 & 3.55 & 110.83 & 11.91 & 1.37 & 561.31 \\
\hline Straw mulch & 35.95 & 42.54 & 44.99 & 12.10 & 3.44 & 101.96 & 11.54 & 1.29 & 515.66 \\
\hline SEm \pm & 0.12 & 0.18 & 0.24 & 0.23 & 0.01 & 2.05 & 0.02 & 0.02 & 0.81 \\
\hline CD at 5\% & 0.36 & 0.55 & 0.99 & 0.68 & 0.02 & 6.09 & 0.05 & 0.06 & 2.42 \\
\hline
\end{tabular}


Table.3 Interaction effect of irrigation levels and mulch on number of fruits per vine, fruit yield per vine (kg) and fruit yield q. ha ${ }^{-1}$ of cucumber $\mathrm{cv}$. Noori $\mathrm{F}_{1}$ hybrid

\begin{tabular}{|c|c|c|c|}
\hline Treatments & Number of fruits per vine & Fruit yield per vine (kg) & Fruit yield $q \cdot h^{-1}$ \\
\hline 1. $\mathbf{I}_{1} \mathbf{M}_{0}$ & 8.15 & 0.89 & 364.62 \\
\hline $\mathbf{I}_{1} \mathbf{M}_{1}$ & 8.84 & 1.11 & 443.62 \\
\hline $\mathbf{I}_{1} \mathbf{M}_{2}$ & 8.58 & 1.05 & 408.93 \\
\hline $\mathbf{I}_{2} \mathbf{M}_{0}$ & 12.36 & 1.19 & 505.65 \\
\hline $\mathbf{I}_{2} \mathbf{M}_{1}$ & 13.41 & 1.48 & 617.77 \\
\hline $\mathbf{I}_{2} \mathbf{M}_{2}$ & 12.96 & 1.37 & 565.93 \\
\hline $\mathbf{I}_{\mathbf{3}} \mathbf{M}_{\mathbf{0}}$ & 12.41 & 1.21 & 506.37 \\
\hline $\mathbf{I}_{\mathbf{3}} \mathbf{M}_{\mathbf{1}}$ & 13.48 & 1.51 & 622.55 \\
\hline 9. $\quad \mathbf{I}_{3} \mathbf{M}_{2}$ & 13.08 & 1.44 & 572.12 \\
\hline$\overline{\text { SEm } \pm}$ & 0.04 & 0.04 & 1.82 \\
\hline CD at $5 \%$ & 0.12 & 0.13 & 5.40 \\
\hline
\end{tabular}


The maximum yield was obtained under black polythene mulch $(1.37 \mathrm{~kg})$ followed by straw mulch $(1.29 \mathrm{~kg})$ and minimum under without mulch $(1.10 \mathrm{~kg})$.

\section{Fruit yield per hector}

A perusal of data (Table 2) showed that levels of drip irrigation and using different type of mulches significantly increased fruit yield. The higher fruit yield of cucumber $(567.03 \mathrm{q}$ $\mathrm{ha}^{-1}$ ) at 1.0 ETc and in case of black polythene mulch $\left(561.31 \mathrm{q} \mathrm{ha}^{-1}\right)$ was recorded.

\section{Interaction effect of irrigation levels and mulches on}

\section{Number of fruit per vine}

Experimental data (Table 3) showed that interaction effect of various drip irrigation and mulches significantly influenced number of fruits per vine. Interaction effect of 1.0 ETc + black polythene mulch recorded highest number of fruits (13.48) per vine which was at par with $0.8 \mathrm{ETc}+$ black polythene mulch (13.41).

\section{Fruit yield per vine}

Experimental results (Table 3) showed that interaction effect of drip irrigation levels and mulching significantly influenced fruit yield per vine. Irrigation at $1.0 \mathrm{ETc}+$ black polythene mulch recorded highest fruit yield $(1.51 \mathrm{~kg})$ per vine but, remained statistically at par with $0.8 \mathrm{ETc}+$ black polythene mulch $(1.48 \mathrm{~kg})$. Whereas, minimum fruit yield $(0.89 \mathrm{~kg})$ per vine was recorded with treatment combination of $0.6 \mathrm{ETc}+$ no mulch.

\section{Fruit yield}

A perusal of data (Table 4.11) revealed that drip irrigation and mulch had significant effect on yield of cucumber. Irrigation level of 1.0 ETc + black polythene mulch recorded maximum yield (622.55 $\left.\mathrm{q} \mathrm{ha}^{-1}\right)$ as compared to all other combinations, however was at par with $0.8 \mathrm{ETc}+$ black polythene mulch.

\section{Growth}

Drip irrigation had significant effect on growth attributes viz. number of branches per vine, length of vine, number of leaves per vine and leaf area per plant when use different level of (0.6, 0.8 and 1.0 ETc) drip irrigation levels. Thus highest values of all these parameters were recorded at 1.0 ETc. However, 0.8 and 1.0 ETc gave at par branches per vine, length of vine, leaves per vine and leaf area per plant (Table 1). Similar findings were also reported by Ningaraju and Joseph (2014) in pickling melon (Cucumis melo) grown under drip irrigation. The increased growth attributes under drip irrigation might have resulted due to better utilization of water (Manfrinato, 1971), higher uptake of nutrients (Bafna et al., 1993) and excellent soil-water-air relationship with higher oxygen concentration in the root zone (Gornat et al., 1973).

The results revealed that different types of mulching materials significantly influenced the growth parameters viz. branches per vine, length of vine, leaves per vine and leaf area per plant (Table 1). Among different mulching treatments, black plastic mulch resulted in higher number of branches per vine, length of vine, number of leaves per vine and leaf area per plant.

The increase in growth parameters with mulch may be due to minimized evaporation loss and extended retention of moisture. Similar results have been reported by Parmar, et al., (2013), Dean ban et al., (2004), Ansary and Roy (2005) in watermelon, Al-Majali and Kasrawi (1995) in muskmelon, Hallidri et al., (2001) in cucumber. 


\section{Flowering}

Number of days to first flowering, fruiting and harvest were significantly influenced by different levels of irrigation through drip. Significantly less days were taken to first flowering, fruiting and harvesting at $1.0 \mathrm{ETc}$ (Table 2). This might be due to the fact that drip irrigation level at 1.0 ETc resulted in optimum vegetative growth and carbohydrate accumulation which induced early flowering, fruiting and harvesting, assisted by more availability of water. Sufficient water application is important for horticultural crops because water shortage in soil can cause flower and fruit drop (Kaya et al., 2005).

Flowering attributes viz. days to first flowering, fruiting and harvesting (Table 2) were significantly influenced by different types of mulching material. Results presented in preceding chapter revealed that black polythene mulch resulted in early flowering, fruiting and harvest, whereas 'no mulch treatment' took maximum number of days for flowering, fruiting and harvesting. Using the different types of mulching materials evoked significant influence of minimum days to first flowering and fruit yield was recorded by Khan et al., (2015).

\section{Yield and yield attributing character}

Irrigation schedules significantly influenced yield and yield attributes of cucumber. The highest fruit length, fruit girth, average fruit weight, fruits per vine, fruit yield per vine and fruit yield per hectare were recorded with drip irrigation level at $1.0 \mathrm{ETc}$ which, remained at par with 0.8 ETc (Table 2). Similar findings were also reported by Ningaraju and Joseph (2014) in pickling melon. Similarly, Losada and Rincon (1994) found that water stress strictly influenced fruit set and fruit number. Mao et al., (2003) reported that fresh fruit yield was influenced by total volume of irrigation water at all growth stages and lowest production was recorded with lower level of irrigation.

The various yield parameters viz. fruit length, girth, average fruit weight, number of fruits per vine, fruit yield per vine and yield (Table 2) were higher with black polythene mulch compared to straw mulch and no mulch treatment. This might have been influenced by favorable soil temperature, moisture conditions and pest-disease control under black polythene mulch. The present finding was in collaboration with Johnson et al., (2000). Similar results have been reported by Khan et al., (2015) in sponge gourd, Aniekwe et al., (2015) in cucumber, Arancibia and Motsenbocker (2008) in watermelon and Ibarra-Jimenez et al., (2008) in cucumber.

\section{Interaction}

The interaction effect of irrigation levels and mulching had significant effect on yield attributes viz. fruits per vine, fruit yield per vine and fruit yield per hectare (Table 3 ). The interaction effect of black polythene mulch + irrigation levels at $1.0 \mathrm{ETc}$ registered maximum number of fruits per vine, fruit yield as compared to other irrigation levels + mulching interactions. The interaction between irrigation and mulching increased the yield attributes and fruit quality characters as reported by Alenazi et al., (2015) in watermelon and Deshmukh et al., (2013) in bottle gourd.

On the basis of the results obtained during the present study it may be concluded that:

The maximum number of branches per vine(1.96), length of vine $(3.77 \mathrm{~m})$, number of leaves per vine (28.28) and leaf area (402.84 $\mathrm{cm}^{2}$ ) at harvest was recorded with 1.0 ETc. Further, black polythene mulch gave maximum number of branches per vine 
(1.92), length of vine $(3.97 \mathrm{~m})$ at harvest, number of leaves per vine (27.32) and leaf area $\left(405.75 \mathrm{~cm}^{2}\right)$ at 90 DAT.

Significantly less days were taken to first flowering (36.15), fruiting (42.79) and fruit harvest (45.24) with 1.0 ETc which, remained at par with 0.8 ETc. Further, black polythene mulch taken less days to first flowering (35.24), fruiting (41.71) and harvest (44.11) in comparison to no mulch and straw mulch treatment.

The maximum length $(13.04 \mathrm{~cm})$, girth $(3.67$ $\mathrm{cm})$, fruit weight $(110.52 \mathrm{~g})$, number of fruits per vine (12.99), fruit yield per vine $(1.39 \mathrm{~kg})$ and yield per hectare (567.03 $\mathrm{q} \mathrm{ha}^{-1}$ ) were recorded with $1.0 \mathrm{ETc}$ of drip irrigation, however, remained at par with 0.8 ETc. Among the mulching the maximum length $(13.16 \mathrm{~cm})$, girth $(3.55 \mathrm{~cm})$, fruit weight (110.83 g), number of fruits per vine (11.91), fruit yield per vine $(1.37 \mathrm{~kg})$ and yield per hectare $\left(561.31 \mathrm{q} \mathrm{ha}^{-1}\right)$ were recorded with black polythene mulch than other mulch treatments.

The interaction effect of treatment combination 1.0 ETc + black polythene mulch recorded the maximum number of fruits per vine $(13.48)$, fruit yield per vine $(1.51 \mathrm{~kg})$ and fruit yield (622.55 $\left.\mathrm{q} \mathrm{ha}^{-1}\right)$ as compared to other treatment combinations. Whereas, the minimum number of fruits per vine (8.15), yield per vine $(0.89 \mathrm{~kg})$ and fruit yield (364.62 $\mathrm{q} \mathrm{ha}^{-1}$ ) were recorded with the treatment combination of 60 per cent ETc + without mulch.

\section{References}

Alenazi, M., Abdel-Razzak, H., Ibrahim, A., Wahb-Allah, M. and Alsadon, A. 2015. Response of muskmelon cultivars to plastic mulch and irrigation regimes under greenhouse conditions, Journal of
Animal \& Plant Sciences, 25(5): 13981410.

Al-Majali, M. A. and Kasrawi, M. A. 1995. Plastic mulch use and method of planting influences on rainfed muskmelon production. Pure and Applied Sci., 22(4): 1039-1054

Aniekwe, N.L. and Anike, N.T. 2015. Effects of different mulching materials and plant densities on the environment, growth and yield of cucumber. Journal of Agriculture and Veterinary Science, 8: 64-72.

Ansary, S. H. and Roy, D. C. 2005. Effect of irrigation and mulching on growth, yield and quality of watermelon (Citrullus lanatus Thunb.). Environment and Ecology, 23(Spl-1): 141-143.

Arancibia, R. A. and Motsenbocker, C. E. 2008. Differential watermelon fruit size distribution in response to plastic mulch and spunbonded polyester rowcover. Hort. Tech., 18(1): 45-52.

Bafna, A. M., Deftardar, S. Y., Khade, K. K., Patel, P. V. and Dhotre, R. S. 1993. Utilization of nitrogen and water by tomato under drip irrigation system. Journal of Water Management, 1(1): 15.

Dean Ban.; Zanic K.; Dumicic, G.; Culjak, T. G. and Ban S. G. 2004. The type of polythene mulch impacts vegetative growth, yield and aphid populations in watermelon production. J. Food, Agri. and Envi., 7(3-4): 543-550.

Deshmukh, Y.K., Sinha, J., Sinha, G. and Verma, P. D. 2013. Effect of mulches and level of irrigation on soil temperature, soil moisture depletion and crop yield for bottle gourd (Lagenaria siceraria). International Journal of Applied Engineering and Technology, 3(3): 29-35.

Dunage, V. S., Balakrishnan, P. and Patil, M. G. 2009. Water use efficiency and economics of tomato using drip 
irrigation under net house conditions. Karnataka Journal of Agriculture Sciences, 22(1): 133-136.

Gornat, B., Goldberg, D., Rimon, D. and Ben, A. J. 1973. The physiological effect of water quality and method of application on tomato, cucumber and pepper. Journal of American Society of Horticulture Science, 98(2): 202-205.

Hallidri, M., Fernandez, J, A., Martinez, P.F. and Castilla, N. 2001. Comparison of the different mulching materials on the growth, yield and quality of cucumber (Cucumis sativus L.). ActaHorticulturae., 1(559): 49-54.

Ibarra Jimenez, L., Zermeno Gonzalez, A., Munguia Lopez, J., Quezada Martin, M. A. R. and Rosa Ibarra, M. de La. 2008. Photosynthesis, soil temperature and yield of cucumber as affected by colored plastic mulch. Acta Agriculturae Scandinavica Section B, Plant Soil Science, 58(4): 372-378.

Johnson, J. M., Hough Goldstein, J. A. and Vangessel, M. J. 2000. Effects of Straw Mulch on Pest Insects, Predators, and Weeds in Watermelons and Potatoes. Environmental Entomology, 33: 16321643.

Kaya, C.D. and Kirnak, H.H. 2005. Influence of polyethylene mulch, irrigation regime, and potassium rates on field cucumber yield and related traits. Journal of Plant Nutrition, 28: 17391753.
Khan, S., Pal, M. and Kumar, V. 2015. Influence of different mulches on growth and yield sponge gourd (Luffa clyndrica L.) Plant Archives, 15(1): 393-395.

Losada, H.P. and Rincon R. 1994. Influence of the cropwater status on fruit setting and final fruit number in the processing tomato crop. Acta Horticulturae, 376: 333-336.

Manfrinato, H. A. 1971. Effect of drip irrigation on soil water plant relationship. Second International Drip Irrigation Congress, 446-451.

Mao, Xuesen, Mengyu, L., Xinyuan, W., Changming, L., Zhimin, H.and Jinzhi, S. 2003. Effects of deficit irrigation on yield and water use of greenhouse grown cucumber in the North China plain. Agricultural Water Management, 61: $219-228$

Nandkarni, K. M. 1927. Indian medical Nandkarni and company, Bombay.

Ningaraju, G. K. and Joseph, P. A. 2014. Effect of drip fertigation on growth and yield of oriental pickling melon (Cucumis melo var. conomon (L.) Makino) under high density planting. International Journal of Scientific and Research Publications, 4(6): 1-5.

Parmar H. N., Polara N. D. and Viradiya R. R. 2013. Effect of mulching material on growth, yield and quality of watermelon (Citrullus Lanatus Thunb) Cv. Kiran. Universal Journal of Agricultural Research, 1(2): 30-37.

\section{How to cite this article:}

Om Prakash Rolaniya, I. M. Verma, S. R. Bhunia and Suresh Kumar Choudhary. 2018. Effect of Irrigation Levels and Mulch on Growth and Yield of Cucumber (Cucumis sativus L.) under Poly House. Int.J.Curr.Microbiol.App.Sci. 7(03): 3748-3756. doi: https://doi.org/10.20546/ijcmas.2018.703.433 